\author{
Ilona Szostak-JośKo \\ Uniwersytet Marii Curie-Skłodowskiej w Lublinie
}

\title{
WARTOŚCI „MIEĆ”, „BYĆ” WŚRÓD UCZNIÓW SZKÓŁ PONADGIMNAZJALNYCH
}

\begin{abstract}
Streszczenie: W świecie nieustannych przemian społecznych, ekonomicznych, kryzysu moralnego, konsumpcyjnego stylu życia, coraz wyraźniej uwidacznia się kontrast między postawami „być” i „mieć”. Celem opracowania jest ukazanie, jakie wartości preferują uczniowie szkół ponadgimnazjalnych. Wyniki badań uzyskane na podstawie Skali Postaw Mieć i Być ks. Bronisława Grulkowskiego wskazały, że 3/4 z 600 przebadanych uczniów identyfikuje się z postawą z pogranicza obu tych grup. Oznacza to, że dążenie do przyjemności, posiadania dóbr materialnych, stabilizacji życiowej, finansowej, konformizmu, jest tak samo ważne dla respondentów, jak przyjaźń, solidarność z innymi ludźmi, niesienie pomocy potrzebującym, samodoskonalenie, rozwijanie zainteresowań czy pogłębianie wiedzy. Otrzymane wyniki stały się podstawą do sformułowania wskazań dla praktyki wychowawczej w zakresie ubogacania i rozwijania postaw uznających prymat wartości duchowych człowieka.
\end{abstract}

Słowa kluczowe: wartości, postawy „być”, „mieć, strategie wychowania, wychowanie moralne

\section{WPROWADZENIE}

Wartości kształtują światopogląd człowieka, absorbują jego myśli, nadają kierunek dążeniom. Równoważą wszystkie wymiary jego życia. Dotyczą sfery psychicznej, fizycznej, duchowej oraz społecznej. Wartości nadają sens naszej egzystencji, odgrywają niezwykle ważną rolę w naszym życiu. Tym samym podejmowanie badań na temat wartości jest niezwykle istotne. Problematyka odnosząca się do postaw „być” $\mathrm{i}$ „mieć” jest podejmowana w ramach różnych teorii, $\mathrm{w}$ różnym znaczeniu, a także $w$ wielu dziedzinach ludzkiego poznania. Zajmowali się nią filozofowie, teologowie, socjologowie, pedagodzy oraz psycholodzy. Kwestia ta budzi również szerokie zainteresowanie społeczne. $\mathrm{W}$ okresie wielu przemian ekonomicznych, 
kulturowych i społecznych, pojawienia się kryzysu moralnego i ekologicznego, liczni autorzy prac naukowych (zob. Fromm 1989; Marcel 1998; Grulkowski 1996, 1998, 2007; Łobocki 2002, Chałas 2003; Denek 2003; Marzec-Tarasińska 2015) odwołują się w analizie egzystencjalnej sytuacji człowieka do rozróżnienia rozumianych opozycyjnie postaw „być” i „mieć”. Ilość badań empirycznych bezpośrednio dotyczących wartości z grupy „być” i „mieć” jest jednak stosunkowo niewielka.

To rodzina, osoby z najbliższego otoczenia, rówieśnicy, nauczyciele, kapłani, ale również środki masowego przekazu, wprowadzają młodego człowieka w świat wartości. U dziecka na podstawie obserwacji i naśladownictwa kształtuje się osobisty pogląd na to, co jest w życiu ważne. Człowiek, dojrzewając fizycznie i psychicznie, dojrzewa również do własnych preferencji w kwestiach wartości i postaw. Stopniowo uczy się postępować, myśleć i żyć według wartości.

Słowo „wartość” pochodzi od łacińskiego valor lub valere (Łobocki 2002, s.71). Niegdyś terminu „wartość" używano tylko w sensie ceny, czyli miał tzw. charakter pieniężny i oznaczał, że coś jest tyle, a tyle warte. Stosunkowo szybko w języku angielskim, francuskim i niemieckim zaczęto odnosić go do tego, co dobre, pożyteczne lub ważne. W języku polskim słowo „wartość” pojawiło się mniej więcej w drugiej połowie XVIII wieku. Oznaczało wtedy tyle, co być cenionym. Zaś wiek później przypisywane mu znaczenie rozszerzono i zaczęto określać nim to co słuszne i dobre (Denek 2003, s. 53-54).

„Wartość” jest to pojęcie abstrakcyjne, które posiada wiele znaczeń. W bogatej literaturze przedmiotu pojawia się wiele eksplikacji tego pojęcia. Desygnatem wartości może być m.in. dobro, wolność, piękno, prawda. Praktycznie wszystkie znaczenia pojęcia „wartość”, stanowią przedmiot zainteresowań jakiejś dyscypliny naukowej. Pomimo że człowiek żyje w świecie wartości oraz według wartości, to jednak bardzo trudno jest je dokładnie określić, wyjaśnić, zrozumieć (Bryzgalski 1999). Wartości zazwyczaj nie są ujmowane wprost, lecz ukazywane poprzez ekspresję i sposób myślenia (Denek 1994, s. 15).

Według słownika języka polskiego, wartości to „cechy stanowiące o walorach ludzi lub rzeczy, albo też to, co się da wyrazić równoważnikiem pieniężnym lub innym środkiem płatniczym" (Szymczak 1981, s. 660). H. Świda i M. Łobocki utożsamiają wartości z tym, co uruchamia motywację człowieka. Twierdzą, że jest to coś godnego pożądania (Łobocki 1993, s. 125). Jedną z bardziej ogólnych definicji wartości przedstawia D. Dobrowolska, która określa je jako wszystko to, co stanowi przedmiot dążeń, postaw i aspiracji człowieka, „jakieś ważne dobra [...] bardziej od innych warte tego, by je w życiu osiągnąć" (za: Dyczewski 1995, s. 104). Zdaniem W. Tatarkiewicza „zdefiniowanie wartości jest trudne, jeśli w ogóle możliwe [...]. To, co wygląda na definicję wartości, jest raczej zastąpieniem wyrazu 
przez inny wyraz, mniej więcej to samo znaczący, co na przykład dobro. Albo jest jego omówieniem" (za: Głuszyński 1983, s. 105).

Wartości determinują ludzkie postawy, dążenia, a także kontakty $\mathrm{z}$ innymi ludźmi. Stanowią standardy myśli, postaw i zachowań. J. Tischner uważa, że każdy człowiek jest artystą, który tworzy samego siebie, oraz że ludzie to swoiste tworzywa, kształtowane właśnie przez wartości. Tak więc wartości obiektywne są nie tylko punktem odniesienia, ale także podstawowym kryterium tworzenia prawdy o samym sobie (za: Bobko 2001, s. 57-61).

Istota wartości w życiu człowieka jest niepodważalna, chociażby za sprawą ich egzystencjonalnego charakteru. To one decydują o jakości i stylu życia, mają wpływ na wszechstronny rozwój i przede wszystkim są czynnikiem kreowania własnej tożsamości (Obuchowski 1972, s. 244). Ponadto wszystkie realizowane wartości są ważnym czynnikiem motywacyjnym oraz znaczącym elementem usprawniającym rozwój poznawczy człowieka. Pobudzają aktywność, mobilizują do działania, a także pozytywnie wpływają na rozwój jego zainteresowań jednostki (Chałas 2003, s. 31).

\section{ISTOTA WARTOŚCI „BYĆ” I „MIEĆ”}

Współcześnie coraz częściej, w różnym kontekście i znaczeniu, używa się pojęć „być” i „mieć”(Jan Paweł II 1982). Problematyka, którą określają owe pojęcia, zaistniała najpierw w egzystencjonalnym nurcie filozofii. Jako pierwszy jej szczegółowej analizy i charakterystyki dokonał G. Marcel. Istnienie człowieka postrzegał on jako możliwość świadomego wyboru sposobu życia (za: Tarnowski 1986, s. 40-48). G. Marcel, twierdził, że jednostka w swojej relacji do świata może wybrać tylko jedną postawę: „mieć” lub „być”. Postawa „mieć” to inaczej postawa egocentryczna, obronna lub „problematyzująca”. Postawa „być” pojmowana jest jako uczestnictwo osoby preferującej tą wartość w życiu innych ludzi. Jest postawą zaangażowania, otwartości. Łączy się z tak zwanym poczuciem bycia „zaproszonym”, „wezwanym” (Marcel 1998, s. 59-63).

Rozróżnienie G. Marcela dość szybko znalazło swoje odzwierciedlenie w psychologii, socjologii, teologii i literaturze. E. Fromm dokonał najbardziej rozbudowanej teoretycznie psychologicznej analizy postaw „być” i „mieć”. Według niego są to dwa odmienne rodzaje struktury charakterologicznej, a dominacja jednego z nich określa to, jak dany człowiek się zachowuje, co myśli i czuje (Fromm 1989, s. 36).

Postawa „być” polega na tym, że człowiek w bardzo konkretny sposób doświadcza dobra i piękna świata, z którym czuje więź. „Być” jest związane z byciem dyspozycyjnym dla innych ludzi i świata. To postawa ufnego, wielowymiarowego, 
szczerego, pełnego zaangażowania w ustosunkowaniu się do świata, we wszystkich jego aspektach (przyroda, inni ludzie, własna osoba, wszechświat). Charakteryzuje się ona dynamicznym (wzrastającym) poczuciem więzi i jedności człowieka z tym wszystkim, co go otacza. Wiąże się z przyjmowaniem otwartej postawy wobec innych osób, pragnieniem wchodzenia z nimi w różne interakcje. Osoba o tej postawie odczuwa ciągłą potrzebę rozwoju i samodoskonalenia. Ponadto czuje wdzięczność, zachwyt wobec świata, a także solidarność z innymi ludźmi. Doświadcza poczucia bezpieczeństwa, przynależności, wspólnoty, a także wolności i odpowiedzialności. Człowiek przyjmujący postawę „być” podziwia świat, potrafi cieszyć się z małych rzeczy, jest osobą spontaniczną, radosną, twórczą. Wytrwale dąży do zamierzonych celów. Jest życzliwy, serdeczny, cierpliwy, wielkoduszny oraz autentyczny. Zdolny do empatii. Osoba identyfikująca się z postawą „być”, w życiu kieruje się ideałami i ma poczucie sensu własnej egzystencji. Jest przekonana o istnieniu (różnie pojmowanej) wieczności (Grulkowski 1998, s. 28-29).

"Mieć" to postawa pełna niepokoju, jednostronna, osobowo bierna, charakteryzująca się utylitarnym podejściem do rzeczywistości. Opiera się na postawie egocentryzmu, poczucia odizolowania, odrębności i obcości w stosunku do świata. Cechą dominującą w postawie „mieć” jest ciągłe poczucie zagrożenia i niepewności co do własnej osoby. Ludzie utożsamiający się z tą postawą odczuwają nieustający wewnętrzny niepokój, niepewność własnej wartości, lęk przed tym, co nowe, niejasne, bądź nieznane. Są to zazwyczaj osoby ostrożne, wiecznie nieusatysfakcjonowane swoją sytuacją życiową, podejrzliwe, zazdrosne, skoncentrowane na sobie, swoich potrzebach. Nastawione na szukanie przyjemności, konformizm. Mają łatwość do wydawania jednoznacznych opinii. Silna koncentracja na rzeczywistości materialnej (rzeczy, pieniądze) u osób o postawie „mieć”, powoduje zawężenie ich zainteresowań. Występuje u nich również zdecydowanie większa obawa przed śmiercią niż u osób identyfikujących się z postawą „być” (Dudzikowa 1993 s. 92; Grulkowski 1996).

Postawy „być” i „mieć” są więc przeciwstawnymi stanowiskami wobec świata w różnych jego aspektach. Postawa „mieć” polega głównie na dążeniu do posiadania dóbr materialnych. Natomiast postawa „być”, opiera się na dążeniu do postawionych sobie celi, rozwijaniu zainteresowań, pogłębianiu wiedzy i pomocy drugiemu człowiekowi. Pojawia się, zatem pytanie: Czy dla współczesnego człowieka liczy się bardziej to, aby być, czy to, żeby mieć, posiadać? 


\section{WYNIKI BADAŃ WŁASNYCH}

W toku badań poszukiwano odpowiedzi na pytanie: jakie wartości preferują uczniowie różnego typu szkół ponadgimnazjalnych (zasadniczych szkół zawodowych, techników, liceów ogólnokształcących) oraz czy istnieją różnice w wartościach uznawanych przez dziewczęta i chłopców z tych szkół.

Badania prowadzono w latach 2014-2016 wśród uczniów szkół ponadgimnazjalnych mieszczących się na terenie województwa lubelskiego: w Zespole Szkół Techniki Rolniczej im. W. Witosa w Piotrowicach, II Liceum Ogólnokształcącym im. Krzysztofa Kamila Baczyńskiego w Świdniku, Zespole Szkół nr 3 im. Juliusza Słowackiego w Kraśniku, Zespole Szkół nr 1 im. Władysława Stanisława Reymontaw Zakrzówku oraz w Zespole Szkół Rzemiosła i Przedsiębiorczości im. Jana Kilińskiego w Lublinie. Warto wspomnieć, że w tych szkołach nigdy wcześniej nie przeprowadzano żadnych badań dotyczących problematyki wartości.

Tabela 1. Spis placówek, w których prowadzono badania

\begin{tabular}{|l|l|}
\hline Typ szkoły ponadgimnazjalnej & \multicolumn{1}{|c|}{ Nazwa placówki } \\
\hline \multirow{4}{*}{ Liceum ogólnokształcące (LO) } & $\begin{array}{l}\text { II Liceum Ogólnokształcące im. Krzysztofa Kamila Baczyńskiego } \\
\text { w Świdniku }\end{array}$ \\
\cline { 2 - 2 } & Zespół Szkół nr 3 im. Juliusza Słowackiego w Kraśniku \\
\cline { 2 - 2 } & Zespół Szkół nr 1 im. Władysława Stanisława Reymonta w Zakrzówku \\
\hline \multirow{3}{*}{ Technikum (T) } & Zespół Szkółnr 3 im. Juliusza Słowackiego w Kraśniku \\
\cline { 2 - 2 } & Zespół Szkół Techniki Rolniczej im. W. Witosa w Piotrowicach \\
\cline { 2 - 2 } & Zespół Szkół nr 1 im. Władysława Stanisława Reymonta w Zakrzówku \\
\hline \multirow{3}{*}{$\begin{array}{l}\text { Zasadnicz szkoła zawodowa } \\
\text { ZSZ) }\end{array}$} & Zespół Szkół Rzemiosła i Przedsiębiorczości im. Jana Kilińskiego w Lublinie \\
\cline { 2 - 2 } & Zespół Szkół nr 3 im. Juliusza Słowackiego w Kraśniku \\
\cline { 2 - 2 } & Zespół Szkół Techniki Rolniczej im. W. Witosa w Piotrowicach \\
\hline
\end{tabular}

Badaniom poddano 600 osób, wśród których znalazło się 228 dziewcząt i 372 chłopców w zbliżonym wieku (16-19 lat). Uczennice stanowiły 38\% wszystkich osób badanych, natomiast uczniowie 62\%. W każdym z poszczególnych typów szkół zbadano dokładnie tyle samo, to jest 200 uczniów. Tym samym zarówno uczniowie zasadniczej szkoły zawodowej, technikum, jak i liceum ogólnokształcącego stanowią 1/3 całej grupy badawczej. Jedna kobieta i 199 mężczyzn to uczniowie zasadniczej szkoły zawodowej, 81 kobiet i 119 mężczyzn uczęszczało do technikum, zaś 146 kobiet i 54 mężczyzn było uczniami liceum ogólnokształcącego.

W badaniach została zastosowana metoda sondażu diagnostycznego. Techniką badawczą było badanie ankietowe, zaś narzędziem badawczym Skala Postaw Mieć i Być B. Grulkowskiego (1998, s. 52-53). 
W kolejnych tabelach przedstawiono wyniki badań dotyczące wartości preferowanych przez badanych uczniów: tabela 2: $\mathrm{z}$ uwzględnieniem typu szkoły ponadgimnazjalnej, do której uczęszczali; tabela 3: z uwzględnieniem płci osób badanych.

Tabela 2. Wartości „mieć” i „być” preferowane przez badanych uczniów z uwzględnieniem typów szkół

\begin{tabular}{|c|c|c|c|c|}
\hline Grupa wartości & ZSZ & $\mathbf{T}$ & LO & Razem \\
\hline Mieć & 32 & 26 & 24 & 82 \\
\hline$\%$ z kolumny & $6 \%$ & $4 \%$ & $4 \%$ & \\
\hline$\%$ z wiersza & $39 \%$ & $32 \%$ & $29 \%$ & \\
\hline$\% \mathrm{z}$ tabeli & $16 \%$ & $13 \%$ & $12 \%$ & $14 \%$ \\
\hline Mieć-być & 149 & 151 & 153 & 453 \\
\hline$\% \mathrm{z}$ kolumny & $25 \%$ & $25 \%$ & $25 \%$ & \\
\hline$\% \mathrm{z}$ wiersza & $33 \%$ & $33 \%$ & $34 \%$ & \\
\hline$\% \mathrm{z}$ tabeli & $74 \%$ & $76 \%$ & $76 \%$ & $75 \%$ \\
\hline Być & 19 & 23 & 23 & 65 \\
\hline$\% \mathrm{z}$ kolumny & $3 \%$ & $4 \%$ & $4 \%$ & \\
\hline$\% \mathrm{z}$ wiersza & $30 \%$ & $35 \%$ & $35 \%$ & \\
\hline$\% \mathrm{z}$ tabeli & $10 \%$ & $11 \%$ & $12 \%$ & $11 \%$ \\
\hline Razem & 200 & 200 & 200 & 600 \\
\hline$\%$ z kolumny & $100 \%$ & $100 \%$ & $100 \%$ & $100 \%$ \\
\hline
\end{tabular}

Analiza uzyskanych wyników globalnych (tabela 1), pozwala zauważyć, że zdecydowana większość uczniów ( $3 / 4$ ogółu badanych) preferuje postawę znajdującą się na pograniczu grupy „mieć” i grupy „być”. Oznacza to, że respondenci mogą dążyć w życiu zarówno do przyjemności i pomnażania dóbr materialnych oraz optymalnie przystosowywać się do otaczającego ich świata (konformizm), traktować innych ludzi instrumentalnie, jako środek uzyskiwania własnych celów, jak również mogą przejawiać postawę empatyczną, twórczą, autentyczną, otwartą na drugiego człowieka i otaczający go świat. Jedynie $14 \%$ całej grupy badanych, opowiedziało się za postawą „mieć”, zaś $11 \%$ za postawą „być”.

Na podstawie danych zawartych w powyższej tabeli, można też zaobserwować, że wyniki otrzymane od osób badane z poszczególnych typów szkół, tj. uczniów zasadniczej szkoły zawodowej, uczniów technikum oraz uczniów liceum ogólnokształcącego, są do siebie bardzo zbliżone. Wśród respondentów, bez względu na typ szkoły ponadgimnazjalnej, dominuje postawa z pogranicza wartości „mieć - być”, na drugim miejscu co do liczebności grupy znalazły się osoby przejawiające w głównej mierze wartości charakteryzujące się postawą konsumpcyjną, zaś najmniej badanych uczniów identyfikuje się z postawą uznającą prymat wyższych wartości duchowych człowieka. 
W tabeli 3 zamieszczono wyniki dotyczące preferowanych wartości „mieć” i „być” w zależności od płci badanych uczniów.

Tabela 3. Wartości „mieć” i „być” preferowane przez badanych uczniów $\mathrm{z}$ uwzględnieniem płci

\begin{tabular}{|c|c|c|c|}
\hline Grupawartości & Kobiety & Mężczyźni & Razem \\
\hline Mieć & 17 & 65 & 82 \\
\hline$\% \mathrm{z}$ kolumny & $3 \%$ & $11 \%$ & \\
\hline$\%$ z wiersza & $21 \%$ & $79 \%$ & \\
\hline$\% \mathrm{z}$ tabeli & $8 \%$ & $18 \%$ & $14 \%$ \\
\hline Mieć-być & 181 & 272 & 453 \\
\hline$\% \mathrm{z}$ kolumny & $30 \%$ & $45 \%$ & \\
\hline$\%$ z wiersza & $40 \%$ & $60 \%$ & \\
\hline$\%$ z tabeli & $79 \%$ & $73 \%$ & $75 \%$ \\
\hline Być & 30 & 35 & 65 \\
\hline$\%$ z kolumny & $5 \%$ & $6 \%$ & \\
\hline$\%$ z wiersza & $46 \%$ & $54 \%$ & \\
\hline$\%$ z tabeli & $13 \%$ & $9 \%$ & $11 \%$ \\
\hline Razem & 228 & 372 & 600 \\
\hline$\%$ z kolumny & $100 \%$ & $100 \%$ & $100 \%$ \\
\hline
\end{tabular}

Zawarte w tabeli dane wskazują, że zarówno dziewczęta jak i chłopcy w zdecydowanej większość preferują grupę wartości „mieć - być”. Jest to 75\% całej grupy badawczej, z czego 30\% stanowią uczennice, a 45\% uczniowie. Niemalże siedmiokrotnie mniej respondentów opowiedziało się za wartościami z grupy „być”, takimi jak równość, solidarność, dobro, piękno, miłość. Wśród nich znalazło się 5\% kobiet i 6\% mężczyzn. Pozostali, tj. 3\% uczennic i 11\% uczniów przejawiało postawę „mieć”, ukierunkowaną na powodzenie materialne. Wśród samych kobiet $8 \%$ opowiedziało się za modelem posiadania, $13 \%$ za modelem bycia i aż $79 \%$ za modelem „mieć - być”. W przypadku mężczyzn sytuacja wygląda podobnie, ponieważ najliczniejszą grupę stanowili uczniowie identyfikujący się z wartościami „mieć - być” (73\%). Niestety blisko co piąty z chłopców (18\%) preferuje wartości „mieć”. Natomiast, w odróżnieniu od dziewcząt, najmniej liczni w grupie uczniów są przedstawiciele grupy wartości „być” - jedyne $9 \%$.

\section{WNIOSKI}

Celem niniejszych badań było wykazanie, które wartości, tj. z grupy „mieć”, „być”, czy może „mieć - być” są preferowane wśród uczniów różnego typu szkół 
ponadgimnazjalnych. Na podstawie uzyskanych wyników można stwierdzić, że młodzi ludzie uczęszczający do szkół ponadgimnazjalnych głównie identyfikują się z wartościami z pogranicza grupy „mieć” i grupy „być”. Tym samym preferują postawę polegającą zarówno na dążeniu do posiadania dóbr materialnych, stabilizacji zawodowej, jak również nastawioną na pomoc drugiemu człowiekowi, pogłębianie wiedzy, rozwijanie zainteresowań, własnej twórczości i empatii (por. Gałkowska-Jakubik 2007, s. 19-21).

Osoby opowiadające się za wartościami typu „być”, tzn. solidaryzujące się z innymi ludźmi, nastawione głównie na samorealizację, doświadczanie dobra i piękna świata, z którym czują autentyczną więź, stanowią najmniej liczną grupę.

Ocena preferowanych wartości przez badanych uczniów w grupie płci męskiej i żeńskiej również wskazuje, że zarówno u kobiet, jak i u mężczyzn dominuje postawa z pogranicza wartości „mieć - być”. Relatywnie więcej dziewcząt niż chłopców ceni w życiu miłość, przyjaźń, wolność, sprawiedliwość, równość, poszanowanie godności i indywidualności drugiego człowieka, dobro (por. Dudzikowa 1993 s. 91-91).

Z przeprowadzonych badań jasno wynika, że uczniowie szkół ponadgimnazjalnych w zdecydowanej większości opowiadają się za wartościami „mieć - być”. Brak całkowitego rozgraniczenia co do identyfikacji z grupą wartości „mieć” lub grupą wartości „być”, może świadczyć o tym, że są one obecne w ich życiu i postępowaniu, oraz że są dla nich tak samo ważne. Prawdopodobne jest również to, że uczniowie nie wiedzą, jak w danej sytuacji mogliby się zachować i nie są w pełni świadomi swoich reakcji, motywacji czy pragnień. Możliwe jest też, że barak odniesienia konkretnych sytuacji do twierdzeń zawartych w SPBiM skutkowało odpowiedziom na „chybił trafił”.

M. Łobocki podkreśla, że od najmłodszych lat każdy człowiek powinien być zaznajomiony z wartościami panującymi w świecie (głównie duchowymi). „Bez stworzenia mu szans zapoznania się z nimi i zarazem ich akceptowania i odrzucania pozbawiony byłby możliwości zaistnienia jako w miarę dojrzała istota ludzka" (Łobocki 2004, s. 32-34). Należy pamiętać, że przede wszystkim postawa rodziców, system wartości w domu rodzinnym i najbliższym otoczeniu dziecka, rzutuje na jego przyszłe postrzeganie siebie, innych ludzi i całego świata (Łukowska 2001, s. 192-197). Według K. Łukowskiej (2001 s. 192) rodzina będąca podstawowym nośnikiem wartości moralnych jest zobowiązana kształtować młodą jednostkę w taki sposób, aby stawała się ona bardziej otwarta i wrażliwa na otaczający ją świat, a posiadanie dóbr materialnych było dla niej narzędziem do tworzenia lepszego świata, a nie celem samym w sobie.

Nie można zapomnieć również o ogromnej roli wychowawców, nauczycieli w kształtowaniu postaw i systemów wartości swoich uczniów. Ważne jest, aby 
jak najwcześniej przekazywać im pozytywne wzory zachowań (zob. Łukowska 2001, Łobocki 2002, Chałas 2005) oraz wskazywać korzyści płynące z obierania postawy życiowej determinowanej wartościami „być”.

\section{WNIOSKI DLA PRAKTYKI PEDAGOGICZNEJ}

Bardzo trudno być nauczycielem w dobie upadku podstawowych wzorców osobowych oraz naczelnych hierarchii wartości, braku dostrzegania wartości absolutnych, ze startą różnicą pomiędzy dobrem a złem, między prawdą a fałszem (Balsamska 2005, s. 3-4).

System wartości wyzwala różnego rodzaju emocje w stosunku do samego siebie, innych ludzi, sytuacji i zjawisk z życia codziennego. Tym samym ma ogromny wpływ na kierunek i sposób zachowania się w różnych sytuacjach życiowych. Można zatem stwierdzić, że wartości stanowią kryterium wyboru działań człowieka, wspierają człowieka w samorealizacji, wyznaczają indywidualne potrzeby, dążenia i cele (Lewandowska-Kidoń, Wosik-Kawala 2003). Wobec powyższego, oczywiste jest, że problematyka wartości stanowi istotny składnik nowego systemu edukacyjnego, a także uniwersalnego modelu aksjologicznego. Wartościom wyznacza się coraz to bardziej znaczące miejsce w procesie wychowania, bo wychowanie bez wartości po prostu nie istnieje. Wartości to ważny element odpowiadający za budowanie sytuacji wychowawczych i procesu wychowania. W procesie tym najbardziej istotne jest, jakie wartości wprowadza się do niego świadomie. Dlatego właściwy, uzasadniony i troskliwy dobór wartości, które nauczyciele chcieliby kształtować u wychowanków jest tak niezwykle ważny (Nowak 2008, s. 378).

Niemal każde wychowanie zawiera w sobie ważny komponent moralny (Straughan 1988, s. 12). Tym samym wychowanie moralne stanowi nieodłączną część jakichkolwiek poczynań wychowawczych. W dobie dzisiejszej cywilizacji zauważa się coraz większe zapotrzebowanie na ten rodzaj wychowania. W miarę rozwoju naukowo-technicznego pojawiają się najróżniejsze problemy natury moralnej, zarówno obserwowane w skali globalnej jak i jednostkowej (Łobocki 2002, s. 17). Współczesna potrzeba wychowania moralnego dzieci i młodzieży odnosi się zarówno do jego wersji neutralnej, jak i normatywnej. Wychowanie moralne w znaczeniu neutralnym, opisowym, polega głównie na zapoznawaniu podopiecznych z różnymi sposobami zachowania i postępowania moralnego, bez sugerowania przez wychowawców ich jednoznacznych ocen. Od nauczycieli wymaga się tutaj nieujawniania własnych preferencji, zwłaszcza w kwestiach problemów moralnych wzbudzających kontrowersje. Głównym zadaniem jest zachęcenie wychowanków do udziału w rzeczowej dyskusji. W tym przypadku dużą wagę przywiązuje się 
do pogłębiania świadomości moralnej uczniów, czyli rozumienia złożoności problemów moralnych oraz umiejętności logicznego i racjonalnego argumentowania, uzasadniania akceptowanych przez siebie wartości, zasad. Natomiast $\mathrm{w}$ wychowaniu moralnym w znaczeniu normatywnym, inaczej oceniającym, chodzi głównie o wpajanie młodym osobom norm, postaw i wartości moralnych, których wyznawanie i realizacja pozwoli im na uzyskanie miana osób moralnych w społeczeństwie. Głównym założeniem jest tutaj to, że nauczyciel wie najlepiej jakie wskazania moralne są najbardziej konieczne i przydatne w życiu uczniów. Tym samym przekonuje swoich podopiecznych o słuszności konkretnych postaw, norm i wartości, a także nakłania do zgodnego z nimi postępowania. Wychowanie na rzecz moralności niezwykle trudno sprowadzić wyłącznie do oddziaływań w znaczeniu opisowym lub wartościującym. Warto, aby te podejścia uzupełniały się wzajemnie i ubogacały (Łobocki 2002, s. 14-21).

Zdaniem K. Ślezińskiego (2012 s. 131) wychowanie do wartości powinno odbywać się w sposób twórczy, aktywny, życzliwy, pozbawiony przymusu, indoktrynacji. Takie możliwości stwarza wykorzystywanie w pracy nauczycieli, pedagogów pewnych strategii wychowania, do których autor zaliczył: strategie dysonansu, świadectwa i stymulacji. W strategii dysonansu wykorzystuje się przede wszystkim doświadczenia dziecka, jego doznania emocjonalno-poznawcze, głównie te negatywne, w których dostrzeże dysonans, sprzeczność pomiędzy własnym sposobem zachowania a właściwą postawą nauczyciela, wychowawcy. Głównym celem w przypadku strategii świadectwa jest przyswojenie sobie przez wychowanka określonych cech innej osoby (autorytetu), będącej reprezentantem danych wartości, zachowań i postaw. Innymi słowy, wyzwala się u młodego człowieka mechanizm identyfikacji rozumiany jako nieświadome przejęcie pewnych cech, postaw oddziaływującego na niego wychowawcy. Ostatnia strategia, tj. strategia stymulacji (inaczej motywowania i pobudzania) polega na konkretyzowaniu wartości już poznanych i zrozumianych przez ucznia oraz na praktycznym ich zastosowaniu, przekładaniu ich na określone kierunki postępowania. Następuje tu interioryzacja wartości (Śleziński 2012, s. 131).

M. Łobocki (2002, s. 21-28) metody służące wprowadzaniu uczniów w świat wartości podzielił na tradycyjne i nowsze. Pierwsze obejmują przede wszystkim: „dawanie przykładu postępowania moralnego, wdrażanie do zachowań moralnych, zapoznawanie $\mathrm{z}$ wiedzą moralną oraz kierowanie procesem samowychowania dzieci i młodzieży”. Metoda dawania przykładu postępowania moralnego jest znana w literaturze psychologicznej i pedagogicznej pod nazwą naśladownictwa, modelowania. Jest najskuteczniejszą metodą przekazywania podopiecznym wiedzy na temat pożądanych wartości i sposobów zachowania, polegającą na oddziaływaniu na nich własnym przykładem. A. Błasiak 2002, s. 233-236) uważa, że każdy 
wychowawca, nauczyciel powinien mieć wykształcony swój indywidualny system wartości, umożliwiający mu oddziaływanie na podopiecznych całym sobą, „swym wewnętrznym i duchowym bogactwem stanowionym przez wartości, które uznaje, akceptuje i prezentuje swoją osobą. Uczeń tylko wtedy będzie mógł doświadczyć wartości wychowawcy, gdy ten będzie przejawiał postawę autentyczną, gdy będzie w stanie przekraczać samego siebie”. Młodzi ludzie wartości moralne przyswajają poprzez obserwację i naśladownictwo rodziców, wychowawców i nauczycieli w ich codziennym życiu. Nieustannie potrzebują przewodników, autorytetów. Kiedy czują się ważni, szanowani i kochani, tym bardziej pragną podążać za ich przykładem (Internet 1: dostęp: 12.09.2016). Warto również pamiętać, że im bardziej przyjacielski i opiekuńczy jest stosunek nauczyciela do uczniów oraz im więcej entuzjazmu przejawia on w relacjach ze swoimi podopiecznymi, tym bardziej pozytywny i większy wywiera na nich wpływ (Bronfenbrenner 1988, s. 179-188).

Wdrażanie do zachowań moralnych, inaczej metoda zadaniowa, polega na powierzaniu uczniom konkretnych zadań do wykonania, służących na ogół dobru określonej grupy, społeczności lub pojedynczym osobom. Innymi słowy związane jest ono z niesieniem pomocy drugiemu człowiekowi.

Dostarczanie wiedzy moralnej polega przede wszystkim na zapoznawaniu uczniów z normami, zasadami, wartościami oraz problemami moralnymi, których doświadczają lub mogą doświadczyć w swoim życiu. Odbywa się to zazwyczaj w formie wykładu, pogadanki, rozmów kierowanych, dyskusji, czyli - najkrócej mówiąc - za pomocą bezpośredniego przekazu słownego. Ważna jest tutaj wiarygodność zachowań i postaw moralnych osób, które ten przekaz artykułują (Łobocki 2002, s. 21-26).

Metoda kierowania procesem samowychowania jest niejako zwieńczeniem całokształtu powyżej opisanych oddziaływań wychowawczych. Wychowywać dzieci i młodzież, znaczy tyle co stymulować ich wszechstronny rozwój, a tym samym pomagać im również $\mathrm{w}$ otwarciu się na wartości. Nauczyciel powinien przygotowywać uczniów do samodzielnego wyznaczania sobie wartościowych celów, dążeń do odpowiedniego wyboru dróg życiowych i kierowania rozwojem swojej osobowości. Aby te zadania realizować należycie, niezmiernie ważne są osobiste dążenia, postawy i system wartości samych nauczycieli, wychowawców (Internet 2, dostęp: 11.09.2016). Bardzo ważne wydaje się tutaj również nieustanne ich samodoskonalenie. Dzięki pracy nad samym sobą, poprzez czytanie pism, książek naukowych, uczestniczenie w rozmaitych szkoleniach, wykładach, konferencjach, podnoszenie swoich kompetencji, gromadzenie i rozpatrywanie informacji zwrotnych czerpanych od uczniów, rodziców, współpracowników, stosowanie różnych technik autosugestii, wizualizacyjnych, relaksacyjnych itp., wychowawcy mogą rozwijać m.in. postawę akceptacji, autentyzmu, rozumienia 
empatycznego, asertywności, uważnego i aktywnego słuchania (Łobocki 1994, s. 126-143; Siek 1990; 1998).

Do tradycyjnych metod wychowania moralnego (poza opisanymi powyżej) można również zaliczyć metodę wzmacniania pozytywnego oraz metodę organizowania środowiska wychowawczego (Krawczyk 1965, s. 197; Łobocki 1990, s. 143-152). Natomiast z nowszych metod warto zainteresować się metodą rozwijania samorządności wśród uczniów, metodą klaryfikowania wartości, czy metodą rozumowania moralnego. Pierwsza z nich polega przede wszystkim na umożliwianiu podopiecznym współdecydowania w rozmaitych sprawach oraz pozostawania przez nich w bliskich relacjach, kontaktach $\mathrm{z}$ opiekunami i ze sobą nawzajem. Samorządność w wychowaniu moralnym sprzyja zgodnemu współżyciu oraz podnoszeniu odpowiedzialności moralnej za swoje decyzje i czyny (Radziewicz, Mirgos 1988, s. 20). Istotą kolejnej z nowszych metod wychowania moralnego, tj. metody klaryfikowania wartości jest uświadamianie sobie przez uczniów własnych uczuć związanych z danymi wartościami. W tym przypadku za wartość uważa się głównie to, co się lubi, co jest uczuciowo bliskie, a nie to, co człowiek powinien uważać za ważne, dobre. Chodzi o to, by uczniowie sami zdecydowali co jest dla nich wartościowe (Straughan 1988, s.16; Łobocki 2002, s. 32). Ostatnią metodą jest metoda rozumowania moralnego - skupiająca się głównie na prowadzeniu dialogu lub dyskusji na temat różnych dylematów moralnych. Zazwyczaj przewiduje: prezentację dylematu moralnego, poszukiwanie jego rozwiązań, ustalenie konsekwencji znalezionych rozwiązań dla osób, których dany dylemat dotyczy, określenie wartości ukrytych w rozważanym dylemacie, wyeksponowanie wartości świadczących o wyższym poziomie rozwoju moralnego (Trempała 1989, s. 20-23).

Poza pedagogicznymi uwarunkowaniami wychowania moralnego, nauczyciele powinni mieć na uwadze również psychospołeczne jego uwarunkowania, do których należy m.in. podmiotowe traktowanie wychowanków, tworzenie wśród nich bezpiecznej, przyjaznej atmosfery oraz umiejętność subtelnego, delikatnego, taktownego porozumiewania się z nimi.

Nauczyciel, przekazując uczniom wartości, może zarówno budzić ich chęć do działania, ciekawość poznawczą, ogólny zapał, pragnienie doskonalenia samych siebie, jak i hamować aktywność swoich uczniów, ich zainteresowania, motywację. Istotne jest zatem, aby potrafił nawiązywać osobowe i dialogowe relacje interpersonalne z wychowankami (Śniegulska 2004). Ważne, by chciał ich poznać, wykazywał szczere zainteresowanie ich sprawami, był wobec nich autentyczny, bezpośredni, otwarty, szanował ich godność osobistą i umacniał w nich poczucie własnej wartości (Okoń 1997, s. 226, Łobocki 2002, s. 34-38). Warto również, by wychowawca stosował wobec swoich podopiecznych język akceptacji, ponieważ 
zachęca on do otwierania się przed drugą osobą, mówienia o sobie, podnosi samoocenę, pomaga wyrażać uczucia, znacząco obniża lęk, poczucie zagrożenia, a tym samym ułatwia wszechstronny rozwój młodych ludzi (Zubrzycka-Maciąg, Wosik-Kawala 2010, s. 67).

Po prześledzeniu czynników pedagogicznych i psychospołecznych warunkujących skuteczność wychowania moralnego, nie sposób nie zgodzić się z opinią S. Wyszyńskiego, mówiącą, że pracę nauczyciela należy traktować i rozumieć jako misję, posłannictwo (Internet 3, dostęp: 5.05.2016). To nauczyciel - dzięki swojej ciężkiej pracy wychowawczej - współtworzy aspiracje i wartości młodych ludzi, jest często żywą częścią ich rozwoju, staje się dla nich autorytetem. Należy pamiętać, że dla właściwego rozwoju ucznia niezwykle ważna jest osoba wychowawcy, nauczyciela, jego autentyczność, wiarygodność, dojrzałość, wyznawana filozofia życiowa oraz jego zaangażowanie w proces wychowania i nauczania. Wychowawcy są odpowiedzialni za kształtowanie sumień, postaw dzieci i młodzieży. Na każdym przedmiocie można tłumaczyć, pokazywać czym jest dobro, piękno, prawda, czym jest „być”, a czym „mieć”, a tym samym uwiarygodniać swoją postawę. Od tego, jakie wartości przyswoją sobie młodzi ludzie, będzie zależało życie społeczne w niedalekiej przyszłości naszego kraju (Szymański 1998). W kontekście powyższego, trudno zaprzeczyć, że tajemnica powodzenia pedagogicznego tkwi nie tyle $\mathrm{w}$ dobrze opracowanych programach, ani też $\mathrm{w}$ wiedzy przedmiotowej nauczycieli, ale przede wszystkim $w$ tym, kim są ci nauczyciele i jakie wartości wyznaczają status ich pedagogicznego „bycia” z drugim człowiekiem (Zubrzycka-Maciąg, Wosik-Kawala 2010).

\section{LITERATURA}

Balsamska M., 2005, Młodzi nas potrzebują. „Uczyć lepiej”, nr 5, s. 3-4.

Błasiak A., 2002, Młodzież - świat wartości. Kraków, s. 233-236.

Bobko A., 2001, Myślenie według wartości. „Znak”, nr 3, s. 57-61.

Bronfenbrenner U., 1988, Dwa światy wychowania USA i ZSRR. Warszawa.

Bryzgalski P., 1999, Kilka refleksji na temat wychowania do wartości. „Wychowawca” nr 6, s. 12.

Chałas K., 2003, Wychowanie ku wartościom. Elementy teorii i praktyki, t. 1: Godność, wolność, odpowiedzialność, tolerancja. Lublin-Kielce.

Chałas K., 2005, Wychowanie ku wartościom-podmiotowe trudności realizacji w praktyce edukacyjnej. W: W. Furmanek (red.), Wartości w pedagogice. Rzeszów.

Denek K., 2003, Dziecko w świetle wartości. Kraków, s. 53-54.

Denek K., 1994, Wartości i cele edukacji szkolnej. Poznań-Toruń, s. 15. 
Dudzikowa M., 1993, Praca młodzieży nad sobq. Z teorii i praktyki. Warszawa.

Dutkiewicz W., 2001, Podstawy metodologii badań do pracy magisterskiej i licencjackiej $z$ pedagogiki. Kielce, s. 50.

Dyczewski L., 1995, Kultura polska w procesie przemian. Lublin, s. 104.

Fromm E., Mieć, czy być, 1989. Tłum. M. Chałubiński. Warszawa, s. 36.

Gałkowska-Jakubik M., 2007, Mieć czy być? Empiryczna weryfikacja koncepcji ErichaFromma. Lublin.

Głuszyński J., 1983, Wartości a wychowanie. W: „Chowanna”, nr 2, s. 105.

Grulkowski B., 1996, Elementy motywacyjne postaw „być” i „mieć”. Lublin, RW KUL.

Grulkowski B., 1998, Postawy „być” i „mieć” a poczucie sensu życia. Gdańsk.

Grulkowski B., 2007, Skala Postaw Być i Mieć. Podręcznik. Kraków.

Jan Paweł II, 1982. Encyklika Laborem exercens. Watykan.

Krawczyk M., 1965. Metody wychowania moralnego. Warszawa.

Lewandowska-Kiedoń T., Wosik-Kawala D., 2003. Wartości uznawane przez wychowanków placówek opiekuńczo-wychowawczych. W: B. Wojciechowska-Charlak (red.) Praca opiekuńczo-wychowawcza. Kielce.

Łobocki M., 1990, W poszukiwaniu skutecznych form wychowania. Warszawa.

Łobocki M., 1993, Pedagogika wobec wartości. W: B. Śliwerski (red.), Kontestacje pedagogiczne. Kraków, s. 125.

Łobocki M., 1994, Organizowanie pracy wychowawczej z dziećmi i młodzieża. Lublin.

Łobocki M., 2002, Wychowanie moralne w zarysie. Kraków.

Łobocki M., 2004, Wybrane problemy wychowania. Lublin.

Łukowska K., 2001, Posiadać więcej, ale czuć się gorzej - konsumpcyjny model współczesnej rodziny. W: H. Liberska, A. Malina (red.), Wybrane problemy współczesnych małżeństw i rodzin. Warszawa.

Marcel G., 1998, Być i mieć. Warszawa, s. 59-63.

Marzec-Tarasińska A., 2015, Mieć czy być - dylematy współczesnego wychowania. W: T. Zubrzycka-Maciąg, M. Korczyński, M. Okrasa (red.), W trosce o wychowanie. Lublin, s. 77-88.

Nowak M., 2008, Teorie i koncepcje wychowania. Warszawa, s. 378.

Obuchowski K., 1972, Psychologia dążeń ludzkich. Warszawa.

Okoń W., 1997, Dziesięć szkół alternatywnych, Warszawa, s. 226.

Radziewicz J., Mirgos M., 1988, O samorządności uczniów w procesie wychowania szkolnego. Warszawa.

Siek S., 1990, Treningi relaksacyjne. Warszawa.

Siek S., 1998, Twoja odpowiedź na stres. Relaksacja, medytacja, Autosugestia (wyd. przejrzane, poprawione i rozszerzone). Wrocław.

Straughan R., 1988, Can we teach children to be good? Basic issues in moral, personal and social education. Wielka Brytania, wyd. 2. 
Szymański M., 1998, Młodzież wobec wartości. Warszawa.

Szymczak M. (red.), 1981, Słownik języka polskiego, t. 3. Warszawa, s. 660.

Śleziński K., 2012, Edukacja filozoficzna w teorii i praktyce. Katowice-Kraków, s. 131. Śniegulska A., 2004, Nauczyciel wychowawca w obliczu wyzwań edukacji aksjologicznej. W: Z. Frączek (red.), Aksjologiczne horyzonty wychowania człowieka XXI w. Rzeszów.

Tarnowski K., 1986, Być czy mieć. „W drodze”, nr 4, s. 40-48.

Trempała J., 1989, Niedyrektywna edukacja moralna: strategie prowadzenia dyskusji i klaryfikowania wartości. „Edukacja”, nr 2, s. 20-23.

Zubrzycka-Maciąg T., Wosik-Kawala D., 2010, Wychowanie w szkole. Wskazówki dla nauczycieli. Lublin, s. 67.

\title{
NETOGRAFIA
}

Internet 1: http://lscdn.pl/pl/centrum-wymiany-wiedzy/wpio/5275,Od-teorii-dopraktyki-WARTOSCI-trzeba-uczyc-przykladem.html (dostęp: 12.09.2016).

Internet 2: http://www.studiagdanskie.gwsh.gda.pl/pdfy/studia4-12.pdf (dostęp: 11.09.2016).

Internet 3: http://www.franciszkanska3.pl/Nauczyciel--zawod-czy-powolanie,a,21941 (dostęp: 5.05.2016).

\section{“TO HAVE” AND “TO BE” ATTITUDES IN SECONDARY SCHOOL STUDENTS}

\begin{abstract}
In the world of continual social and economic changes, morality crisis, consumptionism, the contrast between "to be" and "to have" attitudes is manifesting itself. The aim of this study was to reveal what values are preferred by secondary school students. Results of the research, obtained with the Scale of "to be" and "to have" Attitudes by Bronisław Grulkowski, show that $3 / 4$ of students participating in this study identifies with the attitude on a border of those groups. It means that gaining pleasure, collecting material goods, life and financial stabilisation, conformity are as important for the respondents as friendship, solidarity with others, giving help to people in need, self-improvement, developing one's interests or broadening one's knowledge. Received results provided a foundation for indications for the educational practice in the realm of enrichment and development of attitudes recognising the primacy of human spiritual values.
\end{abstract}

Keywords: values, "to be" attitude, "to have" attitude, strategies for education, moral education 